\title{
Novel Mannich Bases Derived from 2-Substituted Benzimidazole and (Thio)Hydantoin Moieties as Potent Histone Deacetylase 6 (HDAC6)
}

\section{Inhibitors}

\author{
Reda El-Sayed Mansour'1, Hanan Gaber Abdulwahab ${ }^{1 *}$, Hend M. El-Sehrawi ${ }^{1}$
}

\author{
${ }^{1}$ Department of Pharmaceutical Medicinal Chemistry and Drug Design, Faculty of Pharmacy (Girls), Al-Azhar University, \\ Cairo, Egypt. \\ * Correspondence: hanangaber@azhar.edu.eg
}

\begin{abstract}
Novel Mannich bases derived from 2-substituted benzimidazole and (thio) hydantoin moieties, were synthesized as histone deacetylase 6 (HDAC6) inhibitors with potential cytotoxic activity. All derivatives were tested In vitro against HDAC6 enzyme. IR, ${ }^{1} \mathbf{H}$ NMR, ${ }^{13} \mathbf{C}$ NMR and mass spectroscopy confirmed the structure of synthesized compounds. All tested compounds significantly inhibited HDAC6 at nanomolar level. Compound 2c was the most potent presenting significant HDAC6 inhibitory activity $\left(\mathrm{IC}_{\mathbf{5 0}}=97.35 \pm 5.7 \mathrm{nM}\right)$, nearly equipotent to SAHA reference drug $\left(\mathrm{IC}_{\mathbf{5 0}}=91.73 \pm 5.4 \mathrm{nM}\right)$. In vitro cytotoxicity study was also carried out. Compound 2c exhibited potent cytotoxic activity against the tested cells (CCRF-CEM and MOLT-4) showing one digit micromolar $\mathrm{IC}_{50 \mathrm{~s}}$. Compound $2 \mathrm{c}\left(\mathrm{IC}_{50}=3.66 \pm 0.22 \mathrm{uM}\right)$ was 2 -fold more active than SAHA reference drug $\left(\mathrm{IC}_{50}=6.8 \pm 0.41 \mathrm{uM}\right)$ against MOLT-4 cell line. Furthermore, a docking study demonstrated the ability of target Mannich bases to achieve an excellent fitting inside the binding site of HDAC6 enzyme.
\end{abstract}

Keywords: benzimidazole; (thio)hydantoin; HDAC6; Mannich bases; cytotoxicity.

\section{INTRODUCTION}

Leukemia is a lethal type of cancer that leads to hematopoietic malignancies with relatively poor $(20$ $40 \%$ ) patients' survival. Even though the exploration for various therapy, leukemia still the sixth leading cause for death in USA ${ }^{1}$. Recently, a lot of work has been directed to epigenetic changes that accompanied the development of hematopoietic malignancies ${ }^{2}$. These changes play essential roles in regulating gene expression that can eventually induce oncogenic neoplasms ${ }^{3}$. Among these epigenetic changes is the modification of histone acetylation which can account for alteration of DNA accessibility and chromatin structure ${ }^{4}$. Histone acetylation is regulated by histone acetyltransferase (HAT) and histone deacetylase (HDAC) enzymes ${ }^{5}$.

Among HDAC family, HDAC6 is a unique $\mathrm{Zn}^{+2}$ dependent enzyme which plays a vital role in microtubule dynamics and so affects cell proliferation and survival. In addition, HDAC6 acts on nonhistone substrates eg. Hsp90 and peroxiredoxin. HDAC6 has a direct effect on cellular activities including motility, growth of cells, migrations and adhesion ${ }^{6}$. Furthermore, HDAC6 is highly expressed during the development of tumors ${ }^{7,8}$. It has also been reported that inhibition of HDAC6 resulted in apoptosis. Therefore, HDAC6 has been considered as an attractive target for designing potent anticancer candidates. Recently, several pan-HDAC inhibitors eg SAHA (suberoylanilide hydroxamic acid), wereapproved by FDA (Food and Drug Administration) for the management of hematological cancers ${ }^{9,10}$. HDAC6 inhibitors eg. tubastatin $\mathrm{A}^{11}$ and citarinostat $(\mathrm{ACY}-241)^{12}$ have also been reported. Structurally, HDAC inhibitors have common pharmacophoric features: cap-linker-zinc binding group (ZBG) (Figure.1).

Benzimidazole scaffold has attracted considerable attention for the discovery and development of antitumor candidates ${ }^{13,14}$. Several benzimidazolecontaining drugs such as nocodazole and veliparp

Cite this article: Mansour, R., Abdulwahab, H., El-Sehrawi, H. Novel Mannich Bases Derived from 2-Substituted Benzimidazole and (Thio)Hydantoin Moieties as Potent Histone Deacetylase 6 (HDAC6) Inhibitors. Azhar International Journal of Pharmaceutical and Medical Sciences, 2021; 1(3):66 -.74 doi: 10.21608/aijpms.2021.78337.1077 
have been clinically approved for cancer treatment ${ }^{15}$. Moreover, the HDAC inhibitory activity of benzimidazole derivatives has been reported by several research groups ${ }^{16}$ (Figure.2).

On the other hand, hydantoin and thiohydantoin derivatives are five membered heterocyclic compounds that attracted much attention in medicinal chemistry. Hydantoin-based compounds have been reported to exhibit considerable anticancer activities 17. On the other hand, owing to their chelating properties, hydantoin and thiohydantoin have also been recognized to inhibit different metalloenzymes like matrix metalloproteinase ${ }^{18}$ and tryosinase ${ }^{19}$. For these observations, we assumed that hydantoin and thiohydantoin moieties might be considered as nonhydroxamate zinc chelating groups essential for HDAC inhibitory activity.

In the present study, novel Mannich bases derived from 2-substituted benzimidazole and (thio)hydantoin moieties were developed as HDAC6 inhibitors (Figure.3). Following the basic requirements for designing HDAC inhibitors, the benzimidazole nucleus is utilized as a capping moiety that interacts with the enzyme external surface. Whereas, the (thio) hydantoin moiety represents nonhydroxamate $\mathrm{ZBG}$ that can chelate $\mathrm{Zn}^{2+}$ metal at HDAC enzyme binding site. The benzimidazole and the (thio) hydantoin moieties were separated by a $\mathrm{CH}_{2}$ linker. Different substituents $\left(\mathrm{R}=\mathrm{H}, \mathrm{CH}_{3}, \mathrm{Ph}\right)$ were also added to the 2-posoition of benzimidazole ring to discover substituent effect on HDAC inhibition. In this work, all derivatives were screened against HDAC6. In vitro cytotoxicity and docking study were also conducted.

\section{METHODS}

\subsection{Chemistry}

For general remarks, see supplementary file. The staring compounds 1a-c were prepared as illustrated in the literature reviews ${ }^{20,21}$.

\section{Synthesis of benzimidazole derivatives (1a-c)}

A mixture of $o$-phenylenediamine $(0.1 \mathrm{~mol})$ and the corresponding acids, formic acid, acetic acid and benzoic acid $(0.1 \mathrm{~mol})$ in $4 \mathrm{~N} \mathrm{HCl}(15 \mathrm{ml})$, was refluxed for $6-8 \mathrm{~h}$. The reaction mixture was neutralized with $10 \%$ sodium hydroxide solution. The precipitated product was filtered, dried and crystallized from absolute ethanol. Yield $80-90 \%$.

\section{Synthesis of Mannich bases 2a-f:}

A new series of Mannich bases were prepared according to reported procedures ${ }^{22-25}$. A mixture of benzimidazole derivatives 1a-c ( $2 \mathrm{mmol})$, and 38\% formaldehyde solution ( $2 \mathrm{mmol}$ ) was added into the solution of hydantoin or thiohydantoin $(2 \mathrm{mmol})$ in absolute ethanol $(10 \mathrm{ml})$. The reaction mixture was refluxed for 3-4 h. The precipitated products were filtered, dried and crystallized from $99 \%$ ethanol.

\section{5-((1H-benzo $[d]$ imidazol-1-yl)methyl)imidazolid-} ine-2,4-dione (2a)

Yield:(73.90\%); m.p. $190-191{ }^{\circ} \mathrm{C}$; IR (KBr) $\left(\mathrm{cm}^{-1}\right)$ : 3220, $3190(2 \mathrm{NH}), 1780,1698(2 \mathrm{C}=\mathrm{O}) ;{ }^{\mathbf{1}} \mathbf{H}$ NMR (DMSO- $\left.d_{6}\right) \delta$ (ppm): $3.97\left(\mathrm{~d}, 1 \mathrm{H}, \mathrm{CH}_{2}, J=3.9 \mathrm{~Hz}\right)$, 4.07(d, $\left.1 \mathrm{H}, \mathrm{CH}_{2}, J=3.9 \mathrm{~Hz}\right), 4.72-4.76(\mathrm{~m}, 1 \mathrm{H}, \mathrm{CH})$, $6.28\left(\mathrm{~s}, 1 \mathrm{H}, \mathrm{NH}, \mathrm{D}_{2} \mathrm{O}\right.$ exchangeable), $6.42(\mathrm{~s}, 1 \mathrm{H}, \mathrm{NH}$, $\mathrm{D}_{2} \mathrm{O}$ exchangeable), 7.20-7.31 (m, 2H, benzimidazole-H), $7.72(\mathrm{~d}, 1 \mathrm{H}$, benzimidazole- $\mathrm{H}, J=$ $8 \mathrm{~Hz}), 8.21$ (d, $1 \mathrm{H}$, benzimidazole- $\mathrm{H}, J=7.6 \mathrm{~Hz}), 8.33$ (s, 1H, benzimidazole-H); ${ }^{13} \mathbf{C}$ NMR (DMSO- $\left.d_{6}\right) \delta$ (ppm): $48.25\left(\mathrm{CH}_{2}\right), 60.79(\mathrm{CH}), 111.07,119.97$, $123.29,123.32,133.74,144.70,158.81(\mathrm{~N}-\mathrm{C}=\mathrm{N})$, 169.84, $174.36(2 \mathrm{C}=\mathrm{O}) ; \mathrm{MS} \boldsymbol{m} / \boldsymbol{z}(\%): 230.11\left(\mathrm{M}^{+}\right.$, 8.17), 132.69 (1.37), 131.18 (2.27), 100.21(100); Analysis \% for $\mathrm{C}_{11} \mathrm{H}_{10} \mathrm{~N}_{4} \mathrm{O}_{2}$ (230) Calcd. (Found) $\mathrm{C}$, 57.39 (57.13), H, 4.38 (4.09), N, 24.34 (23.99).

\section{5-((2-methyl-1H-benzo[d]imidazol-1-yl)methyl) imidazolidine-2,4-dione (2b)}

Yield:(60.93\%); m.p. $90-92{ }^{\circ} \mathrm{C}$; IR (KBr) $\left(\mathrm{cm}^{-1}\right)$ : 3317, $3300(2 \mathrm{NH}), 1774,1693(2 \mathrm{C}=\mathrm{O}) ;{ }^{1} \mathbf{H}$ NMR (DMSO- $\left.d_{6}\right) \delta(\mathrm{ppm}): 2.60\left(\mathrm{~s}, 3 \mathrm{H}, \mathrm{CH}_{3}\right) 4.01-4.11(\mathrm{~m}$, $2 \mathrm{H}, \mathrm{CH}_{2}$ ), 4.56-4.77 (m, 1H, CH), 7.16-7.24 (m, 2H, benzimidazole- $\mathrm{H}), 7.54-7.58(\mathrm{~m}, 2 \mathrm{H}$, benzimidazole$\mathrm{H}), 8.11$ (s, 1H, NH, $\mathrm{D}_{2} \mathrm{O}$ exchangeable), 10.92 (s, $1 \mathrm{H}, \mathrm{NH}, \mathrm{D}_{2} \mathrm{O}$ exchangeable); ${ }^{13} \mathbf{C}$ NMR (DMSO-d $)$ $\delta$ (ppm): $13.65\left(\mathrm{CH}_{3}\right), 47.70\left(\mathrm{CH}_{2}\right), 61.39(\mathrm{CH})$, $110.47,118.62,122.62,122.9,134.86,142.2,158.83$ $(\mathrm{N}-\mathrm{C}=\mathrm{N}), 169.84,172.36(2 \mathrm{C}=\mathrm{O}) ; \mathrm{MS} \mathbf{m} / \mathbf{z}(\%)$ : $244.22\left(\mathrm{M}^{+}, 9.01\right), 241.62$ (1.32), 130.42 (100); Analysis \% for $\mathrm{C}_{12} \mathrm{H}_{12} \mathrm{~N}_{4} \mathrm{O}_{2}$ (244) Calcd. (Found) $\mathrm{C}$, 59.01 (58.81), H, 4.95 (4.63), N, 22.94 (23.14).

\section{5-((2-phenyl-1H-benzo[ $[d]$ imidazol-1-yl)methyl) imidazolidine-2,4-dione (2c)}

Yield:(75.60\%); m.p. $280-282^{\circ} \mathrm{C}$; IR (KBr) $\left(\mathrm{cm}^{-}\right.$ $\left.{ }^{1}\right): 3209(2 \mathrm{NH}), 1766,1693(2 \mathrm{C}=\mathrm{O}) ;{ }^{1} \mathbf{H}$ NMR $\left(\mathrm{DMSO}-d_{6}\right) \delta(\mathrm{ppm}): 4.00-4.06\left(\mathrm{~m}, 2 \mathrm{H}, \mathrm{CH}_{2}\right), 4.73-$ $4.77(\mathrm{~m}, 1 \mathrm{H}, \mathrm{CH}), 7.27-7.31(\mathrm{~m}, 2 \mathrm{H}$, benzimidazole$\mathrm{H}), 7.49-7.54\left(\mathrm{t}, 1 \mathrm{H}\right.$, phenyl-H), $7.56\left(\mathrm{~s}, 1 \mathrm{H}, \mathrm{NH}, \mathrm{D}_{2} \mathrm{O}\right.$ exchangeable), 7.57 (s, 1H, NH, $\mathrm{D}_{2} \mathrm{O}$ exchangeable), 7.58-7.69 (m, 2H, phenyl-H), $7.98(\mathrm{~d}, 2 \mathrm{H}$, benzimidazole- $\mathrm{H}, J=8.4 \mathrm{~Hz}), 8.24-8.27(\mathrm{~d}, 2 \mathrm{H}$, phenyl-H, $J=8 \mathrm{~Hz})$ ); ${ }^{13} \mathbf{C}$ NMR (DMSO- $\left.d_{6}\right) \delta(\mathrm{ppm})$ : $50.55\left(\mathrm{CH}_{2}\right), 60.27(\mathrm{CH}), 115.34,123.42,127.30$, $129.04,129.10,129.20,129.28,129.57,129.75$, 131.08, 131.23, 138.20, $151.15(\mathrm{~N}-\mathrm{C}=\mathrm{N}), 167.82$, $172.36(2 \mathrm{C}=\mathrm{O}) ; \mathrm{MS} \boldsymbol{m} / \boldsymbol{z}(\%): 306.11\left(\mathrm{M}^{+}, 17.72\right)$, 268.82 (1.42), 64.25 (100); Analysis \% for $\mathrm{C}_{17} \mathrm{H}_{14} \mathrm{~N}_{4} \mathrm{O}_{2}$ (306) Calcd. (Found) C, 66.66 (67.05), H, 4.61 (4.39), N, 18.29 (18.59). 
5-((1H-benzo[d]imidazol-1-yl)methyl)-2-thioxoimi -dazolidin-4-one (2d)

Yield:(80.50\%); m.p. $108-110^{\circ} \mathrm{C}$; IR (KBr) $\left(\mathrm{cm}^{-1}\right)$ : 3143, $3101(2 \mathrm{NH}), 1755,1616(2 \mathrm{C}=\mathrm{O}), 1199(\mathrm{C}=\mathrm{S})$; ${ }^{1} \mathbf{H}$ NMR (DMSO-d $d_{6} \delta$ (ppm): 3.38-3.46 (m, 2H, $\left.\mathrm{CH}_{2}\right)$, 4.55- 4.99 (m, 1H, CH), $6.78\left(\mathrm{~s}, 1 \mathrm{H}, \mathrm{NH}, \mathrm{D}_{2} \mathrm{O}\right.$ exchangeable), 7.22-7.31 (m, 2H, benzimidazole-H), 7.69 (d, 2H, benzimidazole- $\mathrm{H}, J=8 \mathrm{~Hz}), 8.29$ (s, 1H, benzimidazole- $\mathrm{H}), \quad 10.01 \quad\left(\mathrm{~s}, \quad 1 \mathrm{H}, \quad \mathrm{NH}, \quad \mathrm{D}_{2} \mathrm{O}\right.$ exchangeable); ${ }^{13} \mathbf{C}$ NMR (DMSO- $\left.d_{6}\right) \delta$ (ppm): 50.58 $\left(\mathrm{CH}_{2}\right), 67.80(\mathrm{CH}), 111.38,119.82,122.25,122.89$, 133.75, 144.11, $144.34 \quad(\mathrm{~N}-\mathrm{C}=\mathrm{N}), 174.36 \quad(\mathrm{C}=\mathrm{O})$, $181.78(\mathrm{C}=\mathrm{S}) ; \mathrm{MS} \boldsymbol{m} / \boldsymbol{z}(\%): 246.46\left(\mathrm{M}^{+}, 12.94\right)$, 244.21 (4), 240.47 (4.40), 64.40(100); Analysis \% for $\mathrm{C}_{11} \mathrm{H}_{10} \mathrm{~N}_{4} \mathrm{OS}$ (246) Calcd. (Found) C, 53.64 (53.98), H, 4.09 (3.80), N, 22.75 (23.06).

5-((2-methyl-1H-benzo[d]imidazol-1-yl)methyl)-2thioxoimidazolidin-4-one (2e)

Yield:(69.45\%); m.p. $139-140{ }^{\circ} \mathrm{C}$; IR (KBr) $\left(\mathrm{cm}^{-1}\right)$ : 3120 (2NH), 1755, $1616(2 \mathrm{C}=\mathrm{O}), 1149(\mathrm{C}=\mathrm{S}) ;{ }^{1} \mathbf{H}$ NMR (DMSO- $\left.d_{6}\right) \delta$ (ppm): $2.56\left(\mathrm{~s}, 3 \mathrm{H}, \mathrm{CH}_{3}\right) 3.61-$ $3.82\left(\mathrm{~m}, 2 \mathrm{H}, \mathrm{CH}_{2}\right.$ ) $), 4.82-4.99(\mathrm{~m}, 1 \mathrm{H}, \mathrm{CH}), 6.66$ (s, $1 \mathrm{H}, \mathrm{NH}, \mathrm{D}_{2} \mathrm{O}$ exchangeable), 7.16-7.24 (m, 2H, benzimidazole- $\mathrm{H}), 7.53-7.57(\mathrm{~m}, 2 \mathrm{H}$, benzimidazole$\left.\mathrm{H}_{4,7}\right), 10.01$ (s, H, NH, D $2 \mathrm{O}$ exchangeable); ${ }^{13} \mathbf{C}$ NMR $\left(\mathrm{DMSO}-d_{6}\right) \delta$ (ppm): $13.74\left(\mathrm{CH}_{3}\right), 60.27\left(\mathrm{CH}_{2}\right), 66.35$ $(\mathrm{CH}), 110.74,118.32,122.14,122.65,134.99$, 142.02, $\quad 152.25 \quad(\mathrm{~N}-\mathrm{C}=\mathrm{N}), 174.16 \quad(\mathrm{C}=\mathrm{O}), \quad 181.43$ $(\mathrm{C}=\mathrm{S})$; MS $\boldsymbol{m} / \boldsymbol{z}(\%): 260.41\left(\mathrm{M}^{+}, 3.32\right), 257.29$ (3.66), 41.27 (100); Analysis \% for $\mathrm{C}_{12} \mathrm{H}_{12} \mathrm{~N}_{4} \mathrm{OS}$ (260) Calcd. (Found) C, 55.37 (55.69), H, 4.65 (5.03), N, 21.52 (21.14).

5-((2-phenyl-1H-benzo[d] imidazol-1-yl)methyl)-2thioxoimidazolidin-4-one (2f)

Yield:(59.30\%); m.p. 158- $160{ }^{\circ} \mathrm{C}$; IR (KBr) $\left(\mathrm{cm}^{-1}\right)$ : 3232, $3217(2 \mathrm{NH}), 1755,1681(2 \mathrm{C}=\mathrm{O}), 1180(\mathrm{C}=\mathrm{S})$; ${ }^{1}$ H NMR (DMSO- $\left.d_{6}\right) \delta$ (ppm): 3.56-3.83 (m, $2 \mathrm{H}$, $\left.\mathrm{CH}_{2}\right), 4.83-4.97$ (m, 1H, CH), 6.37 (s, 1H, NH, $\mathrm{D}_{2} \mathrm{O}$ exchangeable), 7.27-7.30 (m, $2 \mathrm{H}$, benzimidazole- $\mathrm{H})$, 7.49-7.68 (m, 3H, phenyl-H), $7.97(\mathrm{~d}, 2 \mathrm{H}$, benzimidazole- $\mathrm{H}, J=7.4 \mathrm{~Hz}), 8.24(\mathrm{~d}, 2 \mathrm{H}$, phenyl- $\mathrm{H}$, $J=7 \mathrm{~Hz}), 10.01$ (s, 1H, NH, $\mathrm{D}_{2} \mathrm{O}$ exchangeable); ${ }^{13} \mathbf{C}$ NMR (DMSO- $\left.d_{6}\right) \delta(\mathrm{ppm}): 55.20\left(\mathrm{CH}_{2}\right), 69.60(\mathrm{CH})$, $115.14,124.08,127.58,127.88,129.04,129.34$, $129.69, \quad 129.73,131.20,131.69,133.34,136.88$, $150.68(\mathrm{~N}-\mathrm{C}=\mathrm{N}), 167.79(\mathrm{C}=\mathrm{O}), 173.90(\mathrm{C}=\mathrm{S})$; MS m/z (\%): $322.88\left(\mathrm{M}^{+}, 6.11\right), 318.77(5.11), 59.15$ (100); Analysis \% for $\mathrm{C}_{17} \mathrm{H}_{14} \mathrm{~N}_{4} \mathrm{OS}$ (322) Calcd. (Found) C, 63.34 (62.98), H, 4.38 (4.75), N, 17.38 (17.67).

\subsubsection{In vitro HDAC6 inhibition assay:}

HDAC6 inhibitory activity was measured using BioVision's HDAC6 inhibitor screening kit using SAHA as a reference $\operatorname{drug}^{26}$. For details, see supplementary file.

\subsubsection{Anticancer activity:}

The anticancer activity of compound 2c against CCRF-CEM and MOLT-4 cancer cells was estimated using MTT-based assay kit, Sigma ${ }^{27-29}$. For details, see supplementary file.

\subsection{Figures, Tables and Schemes}

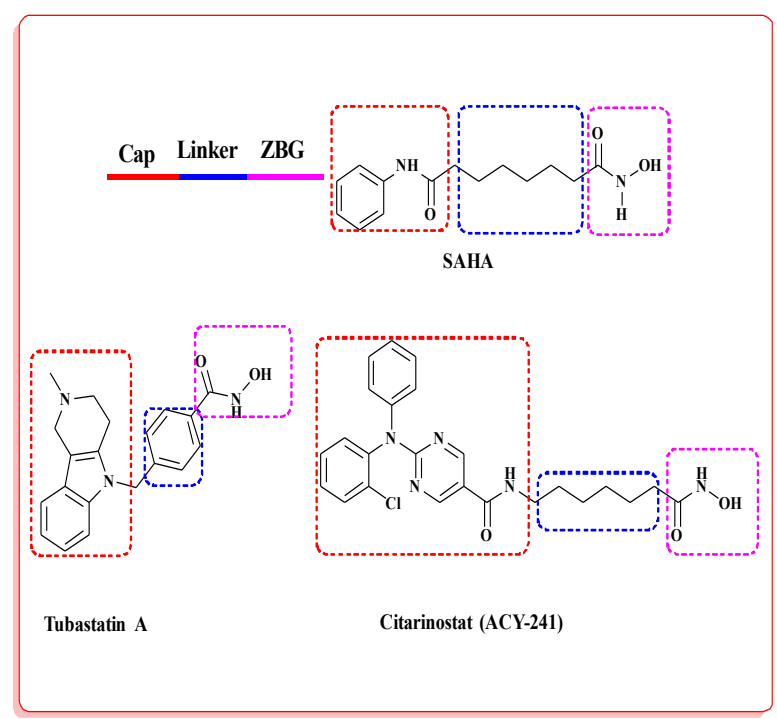

Figure 1. reported histone deacetylase inhibitors

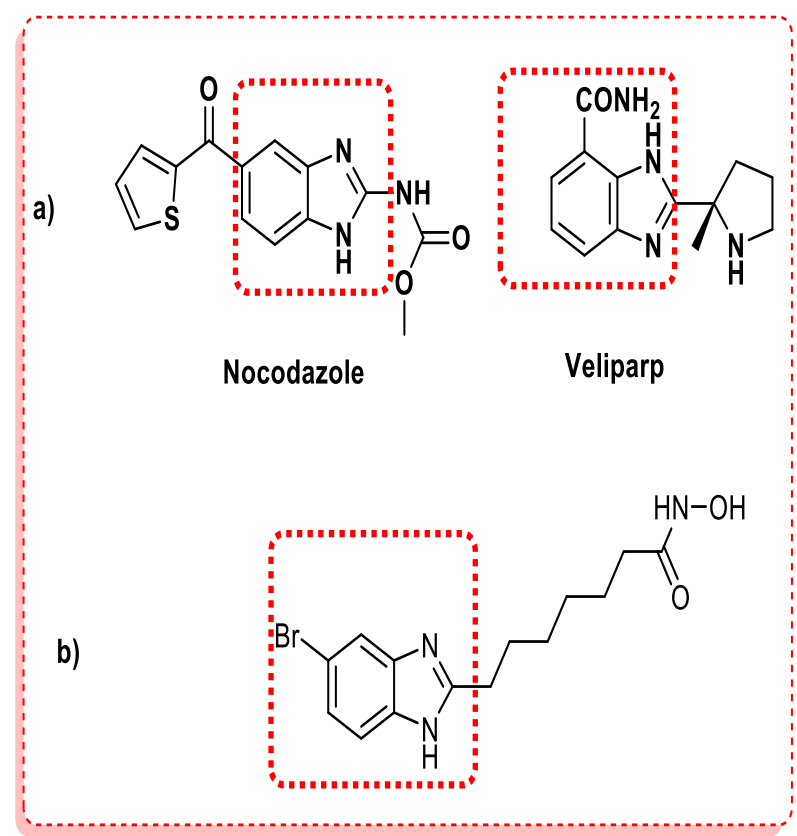

Figure2. a) Clinically approved enzimidazole -containing anticancer drugs.

b) Reported benzimidazole as HDAC inhibitors. 


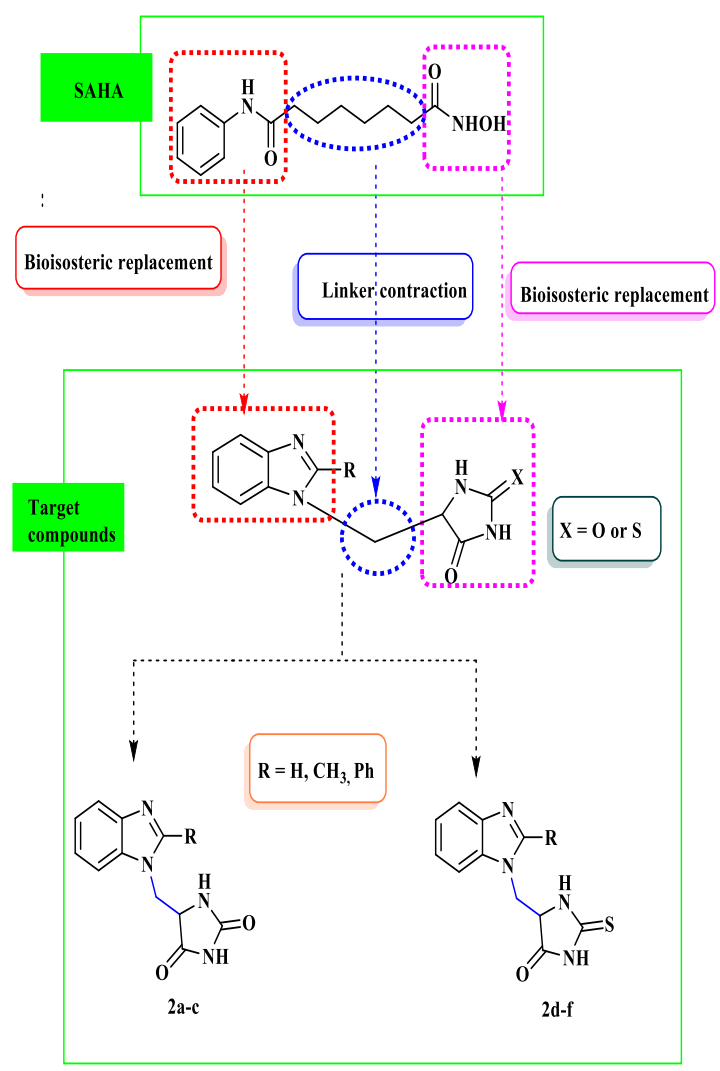

Figure 3. Design of target compounds as HDAC inhibitors.
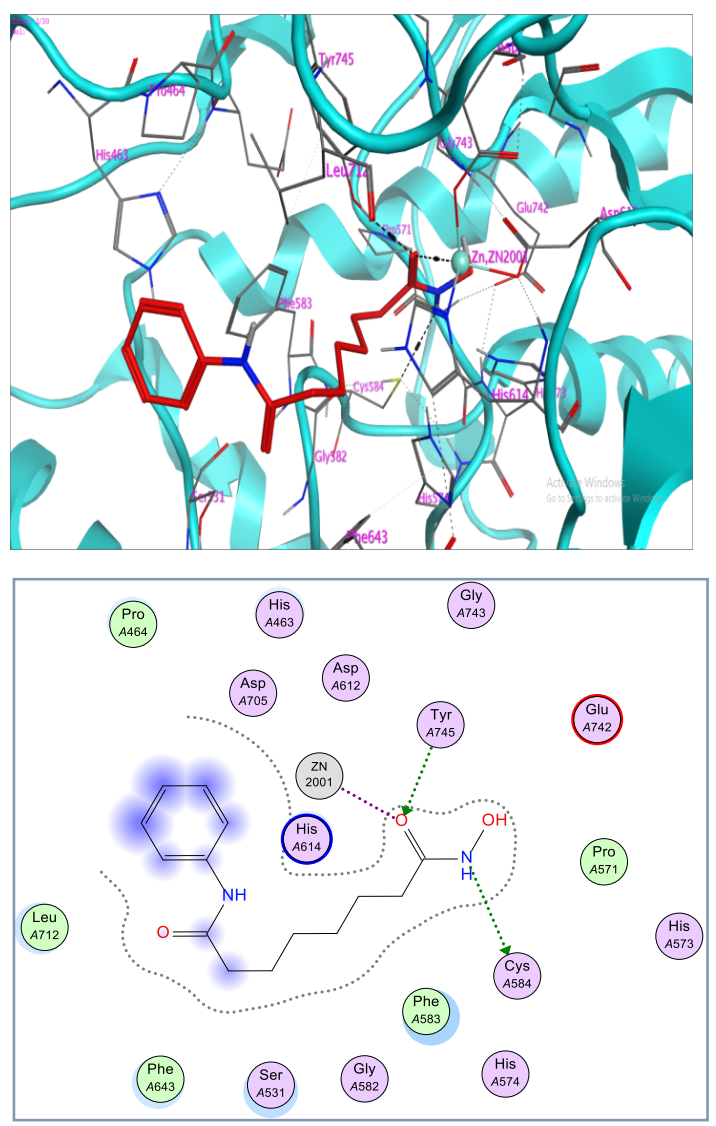

Figure 4a. 2D and 3D of SAHA docked into the active site of HDAC6.
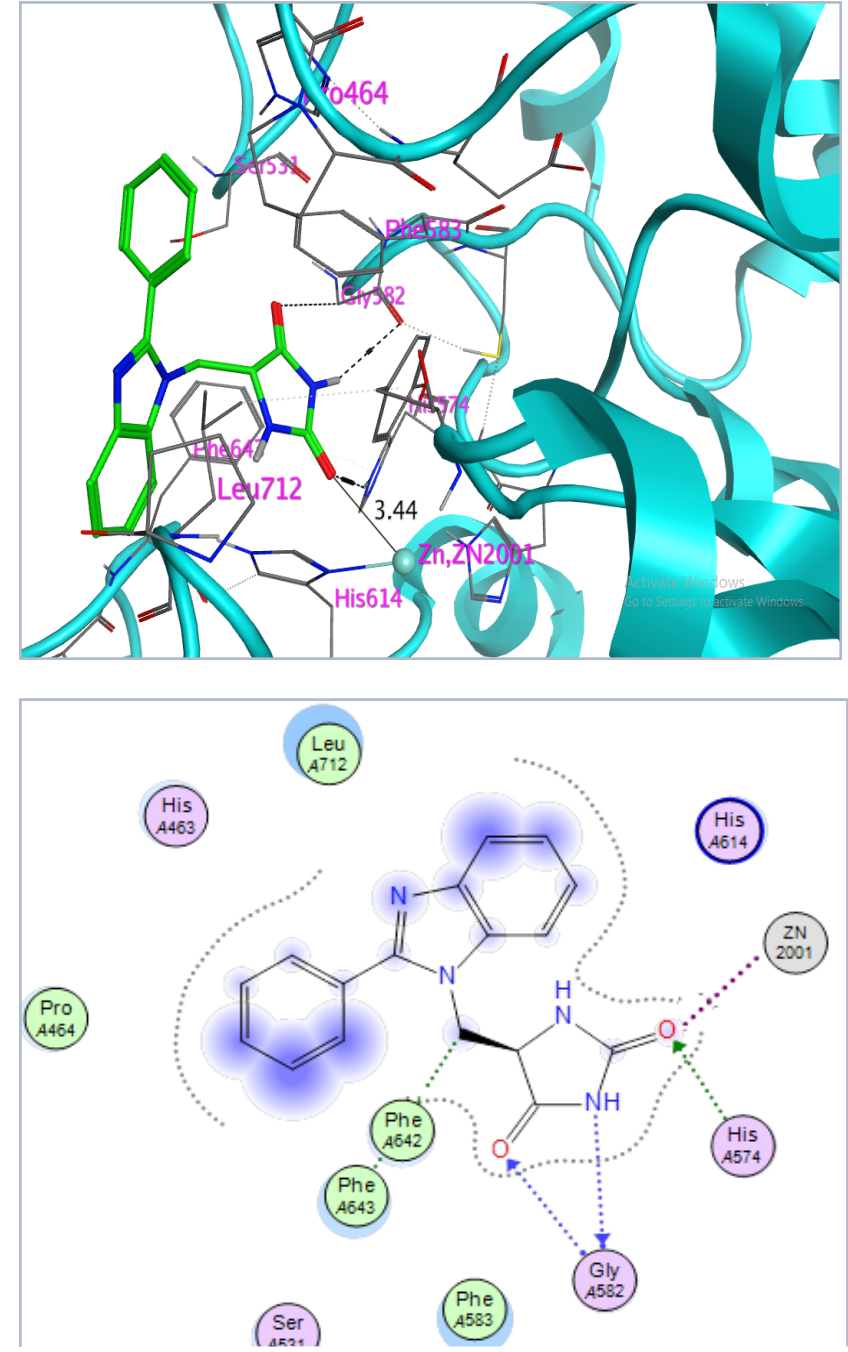

Figure 4b. 2D and 3D of compound 2c docked into the active site of HDAC6.

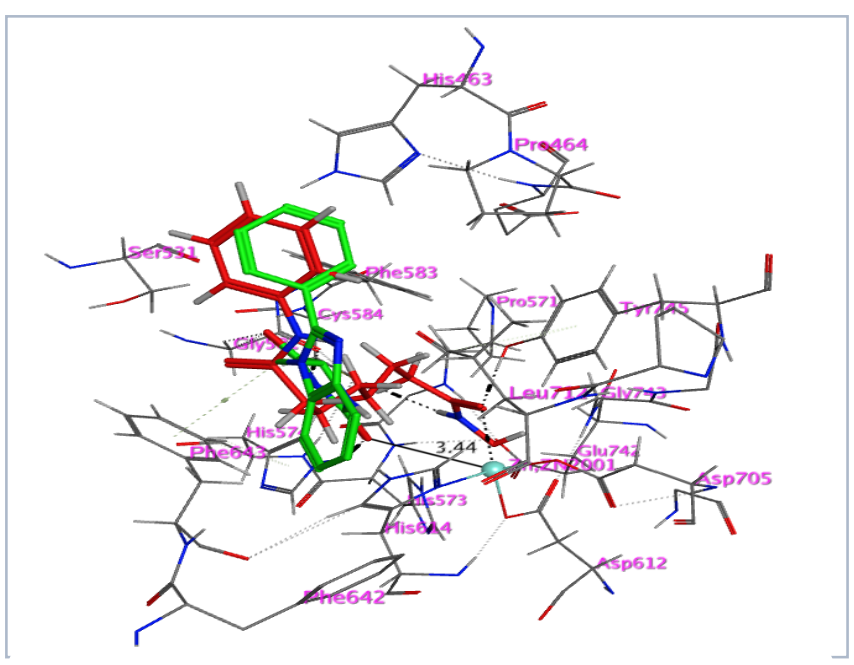

Figure $4 \mathbf{c}$. The overlay of docked $\mathbf{2 c}$ (green color) and SAHA (red color) within the active site of HDAC6. 


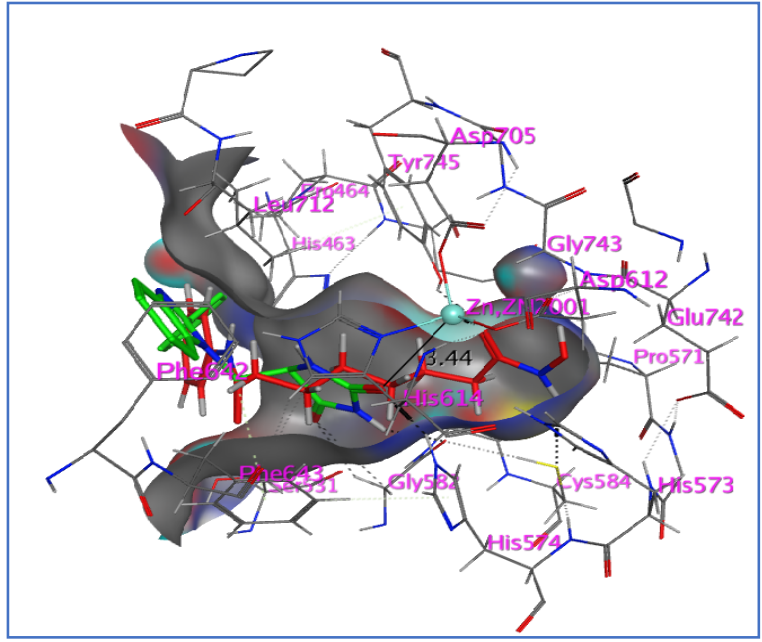

Figure 4d. Side view for compound $\mathbf{2 c}$ (green colour) and SAHA (red colour) inside the binding pocket of HDAC6.

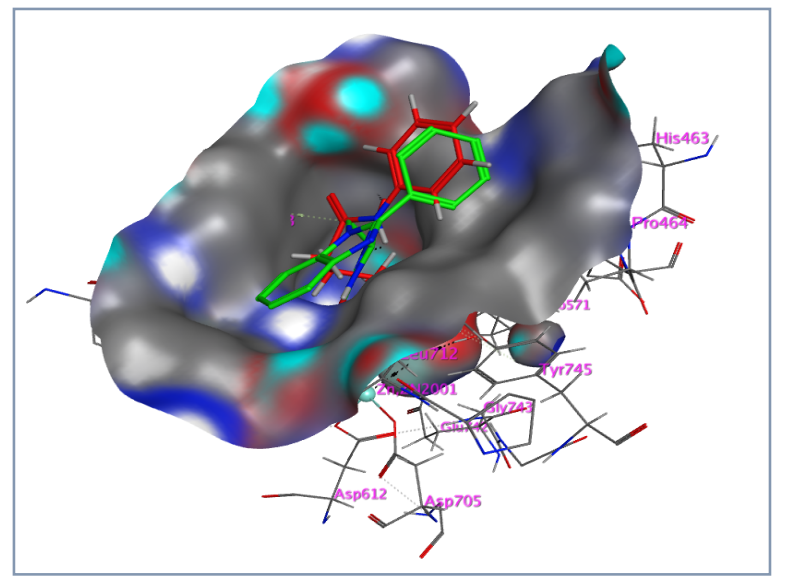

Figure 4e. Top view for compound $2 \mathrm{c}$ (green colour) and SAHA (red colour) inside the binding pocket of HDAC6

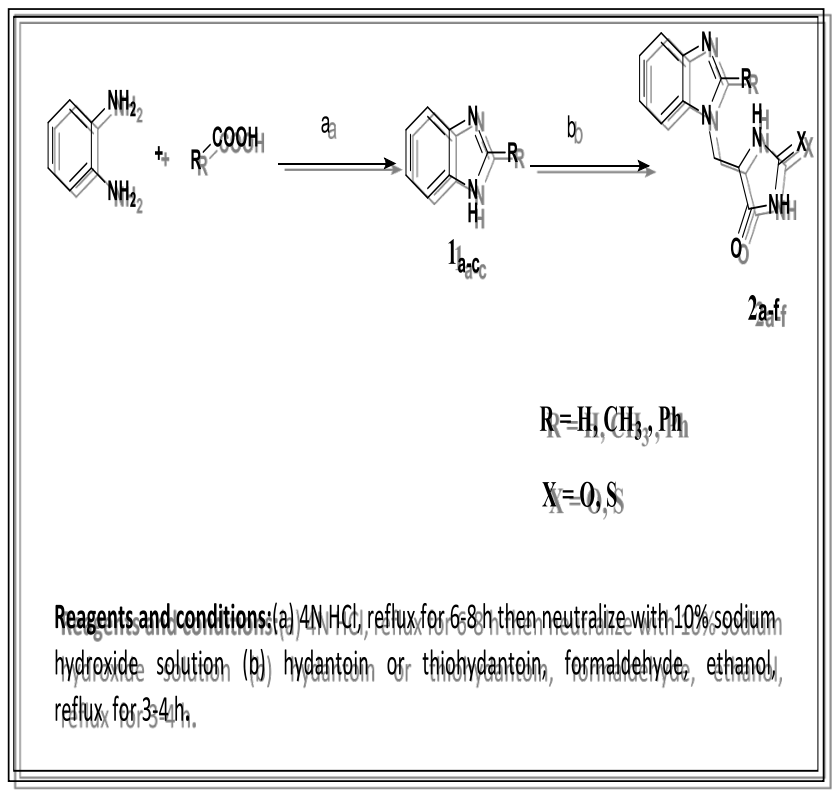

Scheme 1: Synthesis of target Mannich bases 2a-f.

Table 1: HDAC6 inhibitory activity of target compounds.

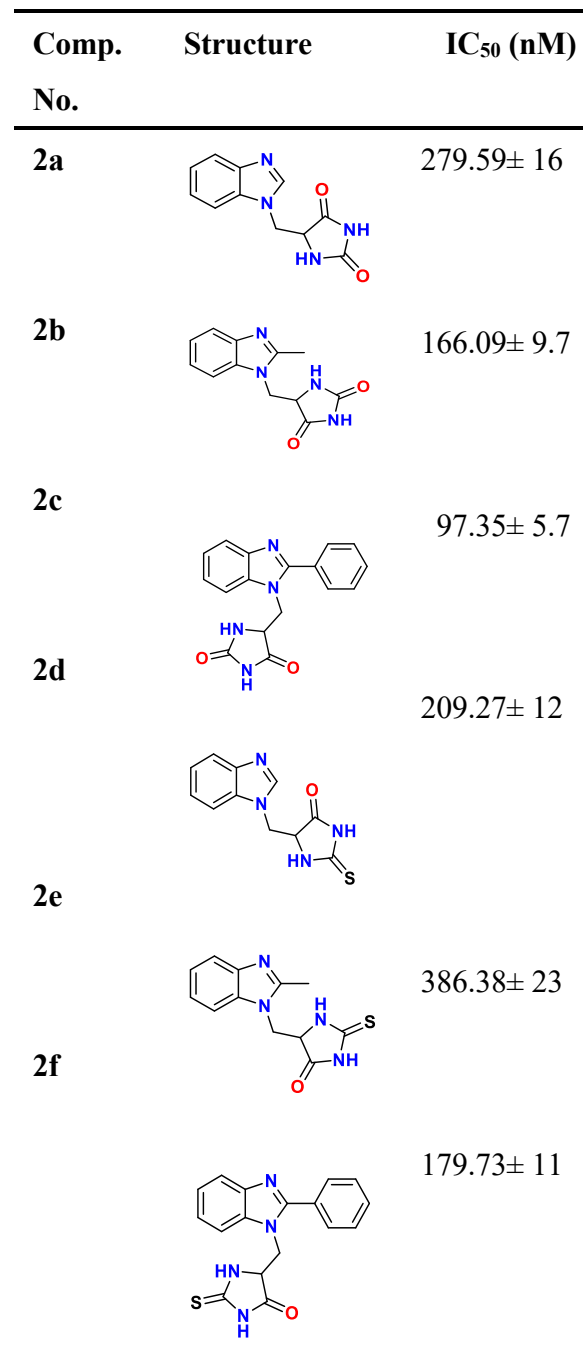

Table 2: In vitro anticancer activity against two human leukaemia cancer cell lines, CCRF-CEM and MOLT-4

\begin{tabular}{|c|c|c|}
\hline Comp. No. & Cytotoxicity & $\mathrm{IC}_{50}(\mathrm{uM})$ \\
\hline & CCRF-CEM & MOLT-4 \\
\hline $2 c$ & $9.67 \pm 0.58$ & $3.66 \pm 0.22$ \\
\hline SAHA & $3.83 \pm 0.23$ & $6.8 \pm 0.41$ \\
\hline
\end{tabular}

Table 3: Docking results for binding interaction of SAHA and $2 \mathrm{c}$ in HDAC6 binding site. 


\begin{tabular}{|c|c|c|c|c|}
\hline $\begin{array}{l}\text { Comp. } \\
\text { No }\end{array}$ & $\begin{array}{l}\text { Docking } \\
\text { score } \\
\text { (Kcal/ } \\
\text { mol) }\end{array}$ & $\begin{array}{l}\text { No. of } \\
\text { H } \\
\text { bonds }\end{array}$ & $\begin{array}{l}\text { Amino } \\
\text { acid } \\
\text { residues } \\
\text { (bond } \\
\text { length } \\
\AA \text { §) }\end{array}$ & $\begin{array}{l}\text { Atom of } \\
\text { compound }\end{array}$ \\
\hline \multirow[t]{9}{*}{ SAHA } & -6.64 & 2 & $\begin{array}{r}\text { Cys } 584 \\
(4.07)\end{array}$ & $\begin{array}{l}\mathrm{NH} \quad \text { of } \\
\text { hydroxymate }\end{array}$ \\
\hline & & & $\begin{array}{r}\text { Tyr } 745 \\
(2.65)\end{array}$ & $\begin{array}{l}\mathrm{C}=\mathrm{O} \quad \text { of } \\
\text { hydroxymate }\end{array}$ \\
\hline & & & $\begin{array}{l}\text { Zn } \\
(2.63)\end{array}$ & $\begin{array}{l}\mathrm{O} \text { of } \mathrm{C}=\mathrm{O} \\
\text { of } \\
\text { hydroymate }\end{array}$ \\
\hline & & & Leu 712 & \\
\hline & & & Ser 531 & Phenyl \\
\hline & & & Phe 583 & $\begin{array}{l}\text { capping } \\
\text { group }\end{array}$ \\
\hline & & & Phe 643 & \\
\hline & & & His 614 & \\
\hline & & & Pro 464 & \\
\hline \multirow[t]{15}{*}{$2 c$} & -4.68 & 3 & $\begin{array}{l}\text { His574 } \\
(2.89)\end{array}$ & $\begin{array}{l}\mathrm{C}=\mathrm{O} \text { of } \\
\text { hydantoin }\end{array}$ \\
\hline & & & $\begin{array}{l}\text { Gly } 582 \\
(3.23)\end{array}$ & $\begin{array}{l}\mathrm{C}=\mathrm{O} \text { of } \\
\text { hydantoin }\end{array}$ \\
\hline & & & $\begin{array}{l}\text { Gly } 582 \\
(3.36)\end{array}$ & $\begin{array}{l}\mathrm{NH} \text { of } \\
\text { hydantoin }\end{array}$ \\
\hline & & & Phe 643 & $\mathrm{CH}_{2}$ of the \\
\hline & & & $(4.45)$ & linker moiety \\
\hline & & & $\begin{array}{l}\mathrm{Zn} \\
(3.44)\end{array}$ & O of hydantoin \\
\hline & & & Leu & \\
\hline & & & 712 & 2-phenyl \\
\hline & & & Ser 531 & benzimidazole \\
\hline & & & Phe 583 & capping group \\
\hline & & & Phe 642 & \\
\hline & & & Phe 643 & \\
\hline & & & His 614 & \\
\hline & & & His 463 & \\
\hline & & & Pro 464 & \\
\hline
\end{tabular}

\section{RESULTS}

\subsection{Chemistry}

In the present work, 2-substitutedbenzimidazoles 1a-c were synthesized via the reaction of $o$-phenylenediamine with the appropriate carboxylic acid following reported procedure ${ }^{20,21}$ (Scheme 1).

It is worth noting that Mannich reaction has a great application in medicinal chemistry as Mannich bases have interesting biological activities eg. anticancer, antibacterial, antiviral and anti-inflammatory ${ }^{22}$. Additionally, aminomethylation of drugs may improve their delivery in the human body and increase the hydrophilic properties through addition of a polar functional group ${ }^{22}$. Following reported procedures $^{23-25}$, benzimidazoles 1a-c were reacted with hydantoin or thiohydantoin and formaldehyde solution to give Mannich bases 2a-f through aminoalkylation reaction (Scheme 1).

\subsection{HDAC6 assay:}

Mannich bases 2a-f, were evaluated against HDAC6 using SAHA as a reference standard (Table 1). All derivatives efficiently suppressed HDAC6 activity showing IC $_{50}$ values in the nanomolar range (97.356 to $368.38 \mathrm{nM}$ ), relative to SAHA reference drug ( IC $_{\mathbf{5 0}}$ $=91.732 \pm 5.4 \mathrm{nM}$ ). Compound $\mathbf{2 c}$ was the most active against HDAC6 enzyme showing a significant HDAC6 inhibitory activity $\left(\mathrm{IC}_{\mathbf{5 0}}=97.356 \pm 5.7 \mathrm{nM}\right)$, nearly equipotent to SAHA $\left(\mathrm{IC}_{\mathbf{5 0}}=91.732 \pm 5.4 \mathrm{nM}\right)$. Analogues 2b, 2d and $\mathbf{2 f}$ revealed half potency of SAHA. While, compounds $2 \mathrm{a}$ and $2 \mathrm{e}$ were the least potent against HDAC6 enzyme.

In vitro anticancer activity:

As mentioned before, SAHA was approved by FDA for the treatment of various hematological cancers including acute myeloid leukemia and multiple myeloma, thus its effectiveness against leukemia is mainly assigned to HDAC inhibition. Thus, compound $2 \mathrm{c}$; the most potent compound against HDAC6, was exposed to anticancer evaluation against two human leukemia cancer cells; CCRFCEM and MOLT-4 using MTT assay ${ }^{27}$ (Table 2).

\section{DISCUSSION}

\subsection{Chemistry}

IR spectra for compounds 2a-c showed sharp absorption bands ranging from 1780 to $1616 \mathrm{~cm}^{-1}$ correlated with the presence of $\mathrm{C}=\mathrm{O}$ groups. Whereas, thiohydantoin derivatives 2 d-f also clearly depicted $\mathrm{C}=\mathrm{S}$ stretching at 1199,1149 and $1180 \mathrm{~cm}^{-1}$ respectively.

Moreover, the ${ }^{1} \mathrm{HNMR}$ analysis for $\mathbf{2} \mathbf{a}$ revealed two doublets at $\delta 3.97$ and $\delta 4.07 \mathrm{ppm}$ ascertaining the presence of $\mathrm{CH}_{2}$ protons in addition to a multiplet in the range of $\delta 4.72-4.76 \mathrm{ppm}$ indicating $\mathrm{CH}$ proton. ${ }^{1} \mathrm{HNMR}$ spectra for $\mathbf{2 b , c}$ and $\mathbf{2 d - f}$ showed two muliplets in the range of $\delta 3.61-4.01$ and $\delta 4.56-4.82$ ppm for $\mathrm{CH}_{2}$ and $\mathrm{CH}$ protons, respectively. 
Furthermore, ${ }^{13} \mathrm{C}$ NMR spectra of 2a-c and $\mathbf{2 d - f}$ exhibited two signals around $\delta 48.25-\delta 60.27$ and $\delta$ 60.27 - $\delta 69.60 \mathrm{ppm}$, corresponding to the two aliphatic carbons $\mathrm{CH}_{2}$ and $\mathrm{CH}$, respectively.

\subsection{HDAC6 assay:}

\subsubsection{Structure-activity relationship:}

Like all reported HDAC inhibitors, the designed compounds have general characteristic structural features necessary for inhibiting HDAC6 enzymes. Herein, these pharmacophoric features represented by benzimidazole capping moiety bearing different substitution on 2-position, $\mathrm{CH}_{2}$ linker and $\mathrm{ZBG}$ that contains either $\mathrm{O}$ or $\mathrm{S}$ atom for binding with $\mathrm{Zn}^{+2}$ ion in the enzyme active site.

Regarding substituents on 2-position of benzimidazole ring, the addition of methyl group in compound $\mathbf{2 b}\left(\mathrm{IC}_{\mathbf{5 0}}=166.09 \pm 9.7 \mathrm{nM}\right)$ resulted in an apparent increase in HDAC6 inhibition, comparing to unsubstituted analogue 2a ( $\left.\mathrm{IC}_{\mathbf{5 0}}=279.59 \pm 16 \mathrm{nM}\right)$. Moreover, a 3-fold increase in HDAC6 inhibition was observed for phenyl benzimidazole derivative 2c $\left(\mathrm{IC}_{50}=97.35 \pm 5.7 \mathrm{nM}\right)$. Similarly, for thiohydantoin compounds $2 \mathbf{d - f}$, phenyl benzimidazole $\mathbf{2 f}$ was much more potent than its unsubstituted (2d) and methyl (2e) analogues.

It is worth mentioning that the type of atom $(\mathrm{X}=$ $\mathrm{O}, \mathrm{S})$ on ZBG has an effective role in HDAC6 inhibitory activity of title compounds. It was noted that the hydantoin derivatives $\mathbf{2} \mathbf{a}, \mathbf{c}(\mathbf{X}=\mathbf{O})$ were more potent than their corresponding thiohydantoin analogues $\mathbf{2 d - f}(\mathbf{X}=\mathbf{S})$.

\subsection{In vitro anticancer activity:}

Compound 2c exhibited potent cytotoxic activity against the two tested cell lines showing onedigit micromolar $\mathrm{IC}_{50}$ s. Noticeably, compound 2c $\left(\mathrm{IC}_{50}=3.66 \pm 0.22 \mathrm{uM}\right)$ was 2-fold more active than SAHA reference drug $\left(\mathrm{IC}_{50}=6.8 \pm 0.41 \mathrm{uM}\right)$ against MOLT -4 cell line. In addition, compound $2 \mathrm{c}$ revealed half potency of SAHA against CCRF-CEM cells with $\mathrm{IC}_{50 \mathrm{~S}}$ of $9.67 \pm 0.58$ and $3.83 \pm 0.23 \mathrm{uM}$, respectively. It was also noted that MOLT-4 cell line was 2-fold more sensitive to compound 2c than CCRF-CEM cell line.

\subsection{Docking study:}

In light of the well-established knowledge of the pharmacophoric parameters (cap, linker and ZBG) that are essential for HDAC6 inhibitory activity, a docking simulation was performed to clarify the interaction of the most promising compound (2c) with HDAC6. The molecular docking study was carried out using MOE 2014.0901 in HDAC6 isoenzyme that is co-crystallized with SAHA (PDB code: $5 \mathrm{EEI})^{30}$. As speculated, compound 2c was approached to the narrow channel of the binding site and chelated with $\mathrm{Zn}^{+2}$ ion at the bottom of catalytic site of HDAC6 (Fig 4a-e). In addition, compound $\mathbf{2 c}$ formed three hydrogen bonds with the side chain residue His 574 and the backbone residue Gly 582 (Table 3). Furthermore, the 2-phenyl benzimidazole capping group formed additional hydrophobic contacts with important residues within the active pocket of HDAC6, including Leu 712, Ser 531, Phe 583, Phe 642, Phe 643, His 614, His 463 and Pro 464 that could contribute to significant improvement in compound activity. Accordingly, the removal or replacement of 2-phenyl benzimidazole with 2methyl benzimidazole induces a great drop in HDAC6 inhibitory activity. This illustrates the important role of phenyl group in benzimidazole capping moiety. Moreover, $\mathrm{CH}_{2}$ moiety of the linker was able to form an arene-H interaction with Phe 643. The obtained binding mode is observably matched with the pervious SAR study and could be considered as a valid explanation for the potent HDAC6 inhibition provoked by compound 2c.

\section{CONCLUSIONS}

New 2-substituted benzimidazole (thio)hydantoin Mannich bases were synthesized as HDAC6 inhibitors. All derivatives inhibited HDAC6 at nanomolar level. Compound 2c was the most potent and displayed HDAC6 inhibition equal to SAHA. In addition, 2c was 2-fold more active than SAHA against MOLT-4 leukemia cells.

Funding statement: This work is not funded.

Conflict of interest: The authors declare no conflict of interest.

Authors consent of publication: This paper is published under the full approval of authors.

Author Contribution: All authors had full access to all the information and took responsibility for data integrity and data analysis accuracy. Authors H.S and H.G designed the study. Author R.M performed the experimental work. Authors H.G and R.M wrote the manuscript. Author H.S supervised the work and revised the whole manuscript. The final manuscript was read and accepted by all the contributors.

List of Abbreviations: SAHA (suberoylanilide hydroxamic acid), FDA (Food and Drug Administration); HDAC6 (histone deacetylase 6), ZBG (zinc binding group). 


\section{REFERENCES}

1. Kadioglu, O., Cao, J., Kosyakova, N., Mrasek, K., Liehr, T., \& Efferth, T. (2016). Genomic and transcriptomic profiling of resistant CEM/ADR-5000 and sensitive CCRF-CEM leukaemia cells for unravelling the full complexity of multi-factorial multidrug resistance. Scientific reports, 6, 36754. https://doi.org/10.1038/srep36754.

2. Feinberg, A. P., \& Tycko, B. (2004). The history of cancer epigenetics. Nature reviews. Cancer, 4(2), 143-153. https://doi.org/10.1038/nrc1279.

3. Heerboth, S., Lapinska, K., Snyder, N., Leary, M., Rollinson, S., \& Sarkar, S. (2014). Use of epigenetic drugs in disease: an overview. Genetics \& epigenetics, 6, 9-19. https://doi.org/10.4137/GEG.S12270.

4. Ell, B., \& Kang, Y. (2013). Transcriptional control of cancer metastasis. Trends in cell biology, 23(12), 603-611. https://doi.org/10.1016/j.tcb.2013.06.001.

5. Seto, E., \& Yoshida, M. (2014). Erasers of histone acetylation: the histone deacetylase enzymes. Cold Spring Harbor perspectives in biology, 6(4), a018713. https://doi.org/10.1101/cshperspect.a018713.

6. Li, T., Zhang, C., Hassan, S., Liu, X., Song, F., Chen, K., Zhang, W., \& Yang, J. (2018). Histone deacetylase 6 in cancer. Journal of hematology \& oncology, 11(1), 111. https://doi.org/10.1186/s13045-018-0654-9.

7. Mottamal, M., Zheng, S., Huang, T. L., \& Wang, G. (2015). Histone deacetylase inhibitors in clinical studies as templates for new anticancer agents. Molecules (Basel, Switzerland),20(3), 3898-3941.

https://doi.org/10.3390/molecules20033898.

8. Bi, G., \& Jiang, G. (2006). The molecular mechanism of HDAC inhibitors in anticancer effects. Cellular \& molecular immunology, 3(4), 285-290.

9. Kelly, W. K., \& Marks, P. A. (2005). Drug insight: Histone deacetylase inhibitors-development of the new targeted anticancer agent suberoylanilide hydroxamic acid. Nature clinical practice. Oncology, 2(3), 150-157. https://doi.org/10.1038/ncponc0106.
10. Tambunan, U. S., Bramantya, N., \& Parikesit, A. A. (2011). In silico modification of suberoylanilide hydroxamic acid (SAHA) as

potential inhibitor for class II histone deacetylase (HDAC). BMC bioinformatics, $12 \quad$ Suppl 13(Suppl 13), S23. https://doi.org/10.1186/14712105-12-S13-S23.

11. Butler, K. V., Kalin, J., Brochier, C., Vistoli, G., Langley, B., \& Kozikowski, A. P. (2010). Rational design and simple chemistry yield a superior, neuroprotective HDAC6 inhibitor, tubastatin A. Journal of the American Chemical Society, 132(31), 10842-10846. https://doi.org/10.1021/ja102758v.

12. Ray, A., Das, D. S., Song, Y., Hideshima, T., Tai, Y. T., Chauhan, D., \& Anderson, K. C. (2018). Combination of a novel HDAC6 inhibitor ACY-241 and anti-PD-L1 antibody enhances anti-tumor immunity and cytotoxicity in multiple myeloma. Leukemia, 32(3), 843-846. https://doi.org/10.1038/leu.2017.322.

13. Alpan, A. S., Zencir, S., Zupkó, I., Coban, G., Réthy, B., Gunes, H. S., \& Topcu, Z. (2009). Biological activity of bis-benzimidazole derivatives on DNA topoisomerase I and HeLa, MCF7 and A431 cells. Journal of enzyme inhibition and medicinal chemistry, 24(3), 844-849. https://doi.org/10.1080/14756360802420831.

14. Zhang, J., Yao, D., Jiang, Y., Huang, J., Yang, S., \& Wang, J. (2017). Synthesis and biological evaluation of benzimidazole derivatives as the G9a Histone Methyltransferase inhibitors that induce autophagy and apoptosis of breast cancer cells. Bioorganic chemistry, 72, 168-181. https://doi.org/10.1016/j.bioorg.2017.04.005.

15. Shrivastava, N., Naim, M. J., Alam, M. J., Nawaz, F., Ahmed, S., \& Alam, O. (2017). Benzimidazole Scaffold as Anticancer Agent: Synthetic Approaches and Structure-Activity Relationship. Archiv der Pharmazie, 350(6), 10.1002/ardp.201700040.

https://doi.org/10.1002/ardp.201700040.

16. Wang, T., Sepulveda, M., Gonzales, P., \& Gately, S. (2013). Identification of novel HDAC inhibitors through cell based screening and their evaluation as potential anticancer agents. Bioorganic \& medicinal chemistry letters, 23(17), 4790-4793. https://doi.org/10.1016/j.bmcl.2013.07.001. 
17. Cho, S., Kim, S. H., \& Shin, D. (2019). Recent applications of hydantoin and thiohydantoin in medicinal chemistry. European journal of medicinal chemistry, 164, $517-545$. https://doi.org/10.1016/j.ejmech.2018.12.066.

18. De Savi, C., Waterson, D., Pape, A., Lamont, S., Hadley, E., Mills, M., Page, K. M., Bowyer, J., \& Maciewicz, R. A. (2013). Hydantoin based inhibitors of MMP13--discovery of AZD6605. Bioorganic \& medicinal chemistry letters, 23(16), 4705-4712. https://doi.org/10.1016/j.bmcl.2013.05.089.

19. Kim, H. R., Lee, H. J., Choi, Y. J., Park, Y. J., Woo, Y., Kim, S. J., Moon, H. R. (2014). Benzylidene-linked thiohydantoin derivatives as inhibitors of tyrosinase and melanogenesis: importance of the $\beta$-phenyl- $\alpha, \beta$ unsaturated carbonyl functionality. Med. Chem. Commun., 5(9), 1410 1417. https://doi.org/10.1039/c4md00171k.

20. Preston, P. N. (1974). Synthesis, reactions, and spectroscopic properties of benzimidazoles. Chemical Reviews, 74(3), 279314. https://doi.org/10.1021/cr60289a001.

21. Sharghi, H., Asemani, O., \& Khalifeh, R. (2008). New One-Pot Procedure for the Synthesis of 2-Substituted Benzimidazoles. Synthetic Communications, $\quad 38(7), \quad 1128$ 1136. https://doi.org/10.1080/00397910701863657.

22. Roman G. (2015). Mannich bases in medicinal chemistry and drug design. European journal of medicinal chemistry, 89, 743-816. https://doi.org/10.1016/j.ejmech.2014.10.076.

23. Tramontini, M., \& Angiolini, L. (1990). Further advances in the chemistry of mannich bases. Tetrahedron, 46(6), 1791-1837 https://doi.org/10.1016/s0040-4020(01)89752-0.

24. Popiołek, Ł., Rzymowska, J., Kosikowska, U., Hordyjewska, A., Wujec, M., \& Malm, A. (2014). Synthesis, antiproliferative and antimicrobial activity of new Mannich bases bearing 1,2,4-triazole moiety. Journal of enzyme inhibition and medicinal chemistry, 29(6), 786-795. https://doi.org/10.3109/14756366.2013.855926.

25. Ozgun, D. O., Yamali, C., Gul, H. I., Taslimi, P., Gulcin, I., Yanik, T., \& Supuran, C. T. (2016). Inhibitory effects of isatin Mannich bases on carbonic anhydrases, acetylcholinesterase, and butyrylcholinesterase. Journal of enzyme inhibition and medicinal chemistry,31(6), 1498-1501. https://doi.org/10.3109/14756366.2016.1149479.
26. Rodríguez-Fonseca, R. A., Sixto-López, Y., Fragoso-Vázquez, M. J., Flores-Mejía, R., CabreraPérez, L. C., Vázquez-Moctezuma, I., RosalesHernández, M. C., Bello, M., Martínez-Archundia, M., Trujillo-Ferrara, J. G., Becerra-Martínez, E., \& Correa-Basurto, J. (2017). Design, Synthesis and Biological Evaluation of a Phenyl Butyric Acid Derivative, N-(4-chlorophenyl)-4phenylbutanamide: A HDAC6 Inhibitor with Antiproliferative Activity on Cervix Cancer and Leukemia Cells. Anti-cancer agents in medicinal chemistry, 17(10), 1441-1454. https://doi.org/10.2174/18715206176661701030928 51.

27. Mosmann T. (1983). Rapid colorimetric assay for cellular growth and survival: application to proliferation and cytotoxicity assays. Journal of immunological methods, 65(1-2), 55-63. https://doi.org/10.1016/0022-1759(83)90303-4.

28. Mahmoud HK, Farghaly TA, Abdulwahab HG, Al-Qurashi NT, Shaaban MR. Novel 2-indolinone thiazole hybrids as sunitinib analogues: Design, synthesis, and potent VEGFR-2 inhibition with potential anti-renal cancer activity. Eur J Med Chem. $2020 \quad$ Dec 15; 208:112752.https://doi.org/10.1016/j.ejmech.2020.1 12752.

29. Sami A. Al-Hussain, Thoraya A. Farghaly, Magdi E.A. Zaki, Hanan G. Abdulwahab, Nadia T. Al-Qurashi, Zeinab A. Muhammad Discovery of novel indolyl-1,2,4-triazole hybrids as potent vascular endothelial growth factor receptor-2 (VEGFR-2) inhibitors with potential anti-renal cancer activity Bioorganic Chemistry 105 (2020)104330.https://doi.org/10.1016/j.bioorg.2020. 104330 .

30. Hai, Y., \& Christianson, D. W. (2016). Histone deacetylase 6 structure and molecular basis of catalysis and inhibition. Nature chemical biology, 12(9), 741-747. https://doi.org/10.1038/nchembio.2134. 